\title{
Antagonistic effect of manganese to cadmium toxicity in the alga Dunaliella salina
}

\author{
Stella Rebhun ${ }^{1}$, Ami Ben-Amotz ${ }^{2, *}$ \\ ${ }^{1}$ Junior Technical College, Technion, Haifa, Israel \\ ${ }^{2}$ Israel Oceanographic \& Limnological Research Ltd, Tel-Shikmona, PO Box 8030, Haifa 31080, Israel
}

\begin{abstract}
The unicellular halotolerant alga Dunaliella salina was exposed to different concentrations of cadmium in the range 9 to $135 \mu \mathrm{M}$. Chlorosis was observed at $25 \mu \mathrm{M}$ cadmium, and inhibition of cell division was established at $45 \mu \mathrm{M}$ cadmium. Biosynthesis of the cellular osmoregulator, glycerol, was not affected by cadmium toxicity throughout the concentration range. Cadmium toxicity was found to be antagonized by low concentrations of manganese. Michaelis-Menten analysis of substrate $\left(\mathrm{Mn}^{2+}\right)-$ inhibitor $\left(\mathrm{Cd}^{2+}\right)$ interactions showed competitive inhibition with the following Ks values at the various concentrations of $\mathrm{Cd}^{2+}: \mathrm{Ks}[\mathrm{Cd}=0]=0.175, \mathrm{Ks}[\mathrm{Cd}=45 \mu \mathrm{M}]=0.175, \mathrm{Ks}[\mathrm{Cd}=90 \mu \mathrm{M}]=0.126, \mathrm{Ks}[\mathrm{Cd}$ $=135 \mu \mathrm{Ml}]=0.10 \mathrm{Ki}$ of cadmium was 0.01 . Results indicate a specific hyperbolic competitive cadmium -manganese interaction on one or both of 2 possible sites: on the cell membrane, or intracellularly on a specific metalo-enzyme. Results imply a possible protection of primary phytoplankton producers by nutrient trace metals against toxic heavy metals present in the oceans.
\end{abstract}

\section{INTRODUCTION}

In some single-celled algae, the toxic effect of cadmium and other heavy metals is associated with depression of cell division rates and consequent increases in cell size (see Fisher et al. 1981 for complete reference list). Since an increase in cell volume reflects enhancement of cellular osmotic components and water content, Dunaliella provides a suitable model to follow the cellular changes of glycerol, the major osmoticum of these halotolerant biflagellates (BenAmoth \& Avron 1978).

Cadmium is a metal with potential cumulative toxicity to humans and various aquatic organisms (Bryan 1971, Nomiyama 1975, Prosi 1981). Cadmium has been found to exert a toxic effect on plants (Weigel 1985) and various unicellular algae such as Chlorella (Rosko \& Rachlin 1975, Hart \& Scaife 1977, Hart et al. 1979, Gipps \& Coller 1980, Rebhun \& Ben-Amotz 1984), Euglena (De Filippis et al. 1981, Bariaud et al. 1985), diatoms (Conway \& Williams 1979, Rachlin et al. 1982, 1983), Dunaliella (Jennings \& Rainbow 1979, Rebhun \& Ben-Amotz 1986), Monochrysis and Isochrysis (Wikfors \& Ukeles 1982), Isochrysis (Li 1980), and other phytoplankton (Kayser \& Sperling 1980, Rabsch \& Elbrächter 1980, Wolter et al. 1984).

\footnotetext{
- Addressee for correspondence
}

Cadmium uptake has been reported in Dunaliella (Jennings \& Rainbow 1979, Rebhun \& Ben-Amotz 1986), but the exact location of cadmium in the cell was not resolved. Our recent paper (Rebhun \& Ben-Amotz 1986) showed that the positively charged $\mathrm{Cd}^{2+}, \mathrm{CdCl}^{+}$ and possibly the neutral $\mathrm{CdCl}_{2}$ (aq) are toxic to Dunaliella.

There has been a long debate on the actual influence on primary productivity of toxic trace metals commonly found in aquatic environments. In nature, the variation of trace metal concentration in seawater is very wide and is affected by many environmental and ecological factors. Marine phytoplankton have shown adaptations enabling them to grow close to industrial polluted areas where the concentration of toxic trace metals is high and variable.

Recent interest in algal biotechnology in general, and in Dunaliella specifically, as a source of natural beta-carotene and other chemicals (Parkinson et al. 1987), has raised the question of the content in algae of heavy metals, with emphasis on toxic metals. The growth of Dunaliella in open salt water ponds and its relatively high resistance to heavy metals may be related to membrane impermeability or to specific cation interactions.

In an attempt to identify the growth requirements of Dunaliella salina, we came across a specific manganese-cadmium interaction which may explain the adap- 
tation of Dunaliella and probably other algae to survival in trace-metal polluted areas.

The present study is based on experimental observations on the manganese-cadmium interaction in Dunaliella salina. The antagonistic mode effect of manganese on cadmium toxicity and uptake is described.

\section{MATERIALS AND METHODS}

\author{
Algae. Dunaliella salina. (Dunal) Teod. UTEX \# LB \\ 200.
}

Growth medium. An artificial medium ( $\mathrm{pH} 7.4)$ was used, containing: $0.75 \mathrm{M} \mathrm{NaCl} 5 \mathrm{mM} \mathrm{MgSO}, 0.3 \mathrm{mM}$ $\mathrm{CaCl}_{2}, 5 \mathrm{mM} \mathrm{KNO}, 0.2 \mathrm{mM} \mathrm{KH}_{2} \mathrm{PO}_{4}, 1.5 \mu \mathrm{M} \mathrm{FeCl}$, $6.0 \mu \mathrm{M}$ EDTA, $50 \mathrm{mM} \mathrm{NaHCO}$ and the trace elements: $0.4 \mu \mathrm{M} \mathrm{Cu}^{2+}, 0.8 \mu \mathrm{M} \mathrm{Zn}^{2+}, 0.4 \mu \mathrm{M} \mathrm{Co}^{2+}, 7.0 \mu \mathrm{M} \mathrm{Mn}^{2+}$, $0.3 \mu \mathrm{M} \mathrm{Mo}^{2+}$ and $185 \mu \mathrm{M} \mathrm{H}_{3} \mathrm{BO}_{3}$. The concentration of EDTA as iron chelator was kept constant at $6.0 \mu \mathrm{M}$ throughout all the growth experiments to avoid variation in the trace elements by the chelation level. Measurements of the concentration of EDTA, not complexed by iron, showed that the concentration of free EDTA in the medium was about $1 \mu \mathrm{M}$. This low level of free EDTA is unlikely to have interfered with the action of cadmium on Dunaliella salina.

All chemicals used were analytical grade. Modifications of the growth medium composition are indicated in the text.

Growth conditions. Late logarithmic phase algae were inoculated in fresh medium to an initial concentration of $10^{4}$ cells $\mathrm{ml}^{-1}$ and were grown at $22 \pm 2{ }^{\circ} \mathrm{C}$ under cool white fluorescent continuous light of $80 \mu \mathrm{E}$ $\mathrm{m}^{-2} \mathrm{~s}^{-1}$ with slow shaking. All cultures were aseptic and bacteria free.

$\mathrm{Cd}$ toxicity. Whenever indicated, $\mathrm{Cd}\left(\mathrm{NO}_{3}\right)_{2}$ atomic absorption grade (Merck) was introduced into the medium in concentrations from 0 to $135 \mu \mathrm{M}$. Algae were grown in the cadmium-enriched medium from the onset of the experiment for a complete growth cycle of about $6 \mathrm{~d}$. In order to identify the ion antagonistic to cadmium toxicity, cultures of Dunaliella salina were grown in the presence of 4 out of 5 routinely added trace elements, i.e. in each culture a different element was missing.

Assays. Algae were assayed daily for cell number, chlorophyll and glycerol. Cells were counted with a Coulter Counter Model ZB. Algal volume was assayed microscopically. Chlorophyll was assayed spectrophotometrically following extraction with $90 \%$ acetone (Jensen 1978). Glycerol was assayed by the acetyl-acetone method (Ben-Amotz \& Avron 1978). Cadmium was assayed in the algae by centrifuging samples and transferring the algal pellet with a small amount of water into pre-weighed crucibles for heating and ashing at $480^{\circ} \mathrm{C}$. The inorganic residue was completely dissolved in acidified distilled water and assayed for cadmium with an atomic absorption spectrophotometer Model IL 951 with an air-acetylene flame. Results were corrected for medium residual $\mathrm{Cd}$
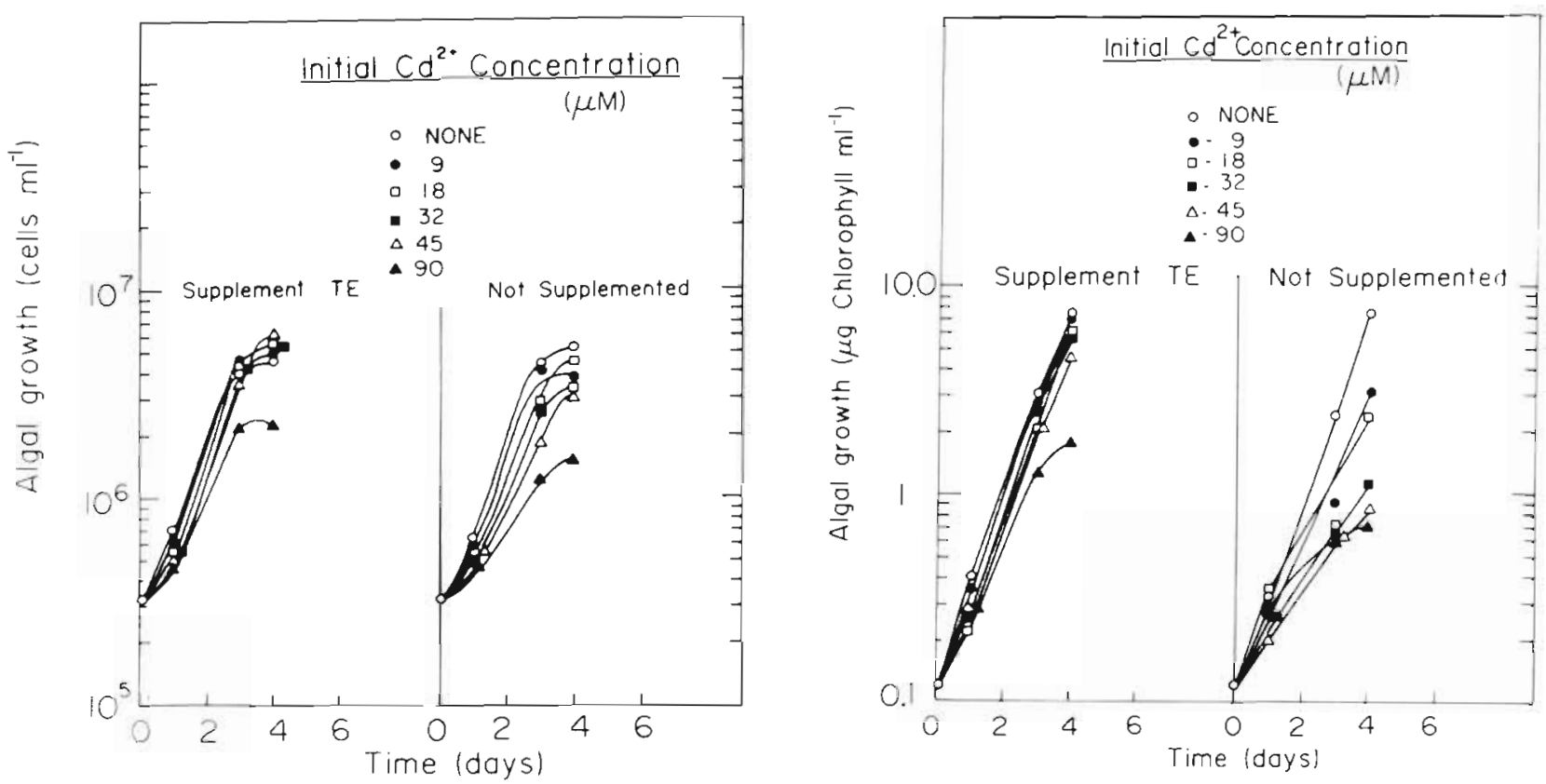

Fig. 1 Dunaliella salina. Effect of $\mathrm{Cd}^{2+}$ on growth in the presence and absence of trace elements (TE). Left: cells; right: chlorophyll. Growth conditions as described in 'Materials \& Methods' 
and for the effect of salts on the cadmium assay by the atomic absorption spectrophotometer.

Statistics. The significance of all growth differences was determined by t-test.

\section{RESULTS}

\section{Cadmium toxicity and trace element antagonism}

Dunaliella salina was found to grow well in the synthetic medium containing $0.75 \mathrm{M} \mathrm{NaCl}$ with no addition of the classical supplemented trace elements $\mathrm{Cu}^{2+}, \mathrm{Zn}^{2+}, \mathrm{Co}^{2+}, \mathrm{Mn}^{2+}$ and $\mathrm{Mo}^{2+}$ (Fig. 1). Most probably the trace elements in the $\mathrm{NaCl}$ supplied the basic needs of the algae for normal cell division and growth, since the addition of trace elements did not produce enhanced cell growth rate nor increased in cell density. However, comparable growth with the addition of cadmium showed cadmium toxicity in the absence of supplemented trace elements. Less than $45 \mu \mathrm{M} \mathrm{Cd}^{2+}$ inhibited growth of trace-element-deficient algae but had no effect on trace-element-enriched algae. The traceelement-enriched algae were inhibited by concentrations of cadmium exceeding $90 \mu \mathrm{M}$.

The general phenomenon of cadmium toxicity was

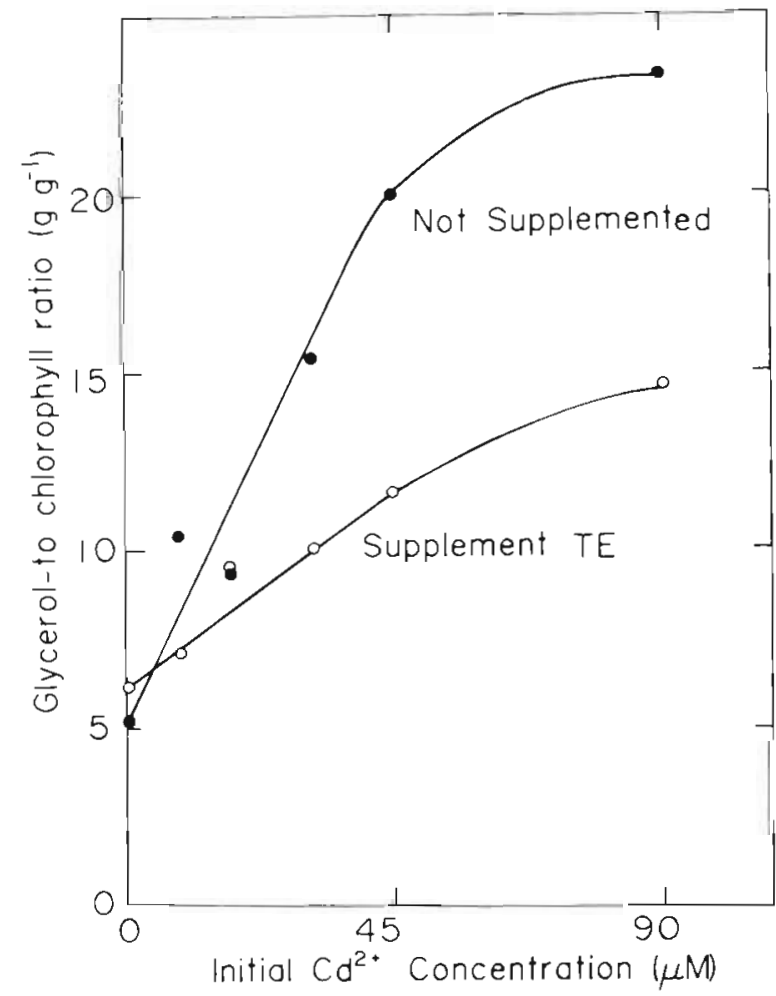

Fig. 2. Dunaliella salina. Effect of $\mathrm{Cd}^{2+}$ on glycerol content in the presence and absence of trace elements (TE). Growth conditions as described in 'Materials and Methods' initially reflected by partial inhibition of chlorophyll biosynthesis and chlorosis. The pigment content of trace-element-enriched algae decreased from 0.75 to $0.25 \mathrm{pg}$ chlorophyll cell ${ }^{-1}$ in Dunaliella salina grown in a $\mathrm{Cd}^{2+}$ concentration of $45 \mu \mathrm{M}$.

The partial inhibition of chlorophyll biosynthesis by cadmium was not reflected in the biosynthesis of glycerol, which is the osmoregulator in Dunaliella. The algae synthesized glycerol at a normal photosynthetic rate irrespective of chlorosis and even under conditions of cadmium inhibiting cell division. As a consequence, the content of glycerol per chlorophyll increased (Fig. 2) in parallel to cell volume enlargement (not shown).

\section{Effect of manganese}

Out of the 5 trace elements routinely added to the medium - $\mathrm{Cu}^{2+}, \mathrm{Zn}^{2+}, \mathrm{Co}^{2+}, \mathrm{Mn}^{2+}$ and $\mathrm{Mo}^{2+}-$ only manganese antagonized the toxic effect of cadmium (Fig. 3). The other trace elements had no effect on cadmium toxicity at nutrient level or at up to 10 times the nutrient concentration. Unimpaired glycerol synthesis and a significant drop in chlorophyll content produced a high glycerol-to-chlorophyll ratio in cadmium-toxicated cells and a normal ratio in cadmium-

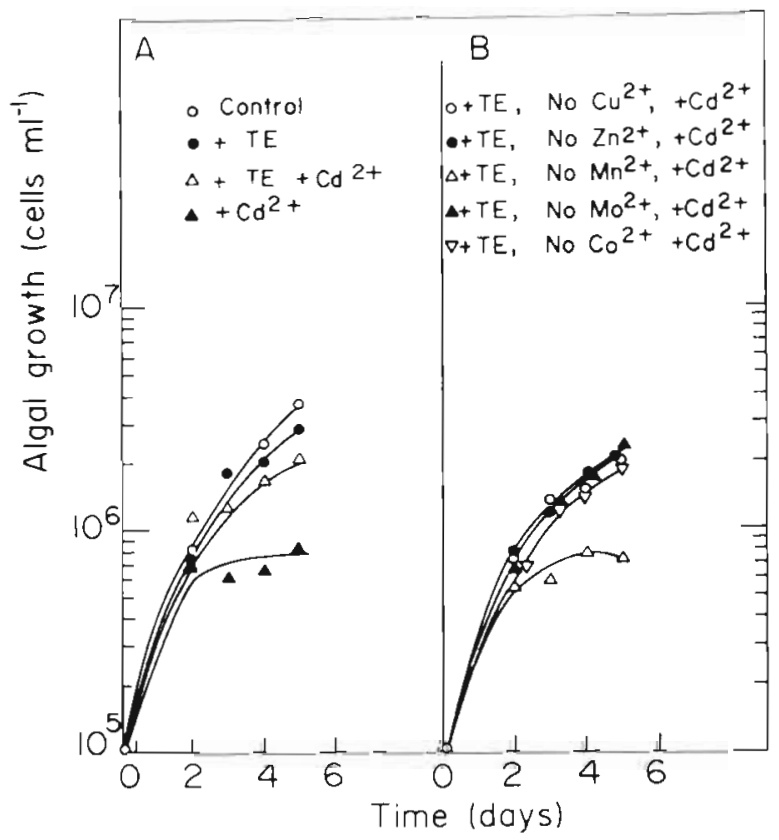

Fig. 3. Dunaliella salina. Effect of trace elements on growth in the presence of $\mathrm{Cd}^{2+}$. Algae were exposed to $45 \mu \mathrm{M} \mathrm{Cd^{2+ }}$ in the presence of (A) all trace elements, or (B) 4 trace elements out of 5 , to determine the antagonistic metal to $\mathrm{Cd}^{2+}$ toxicity 


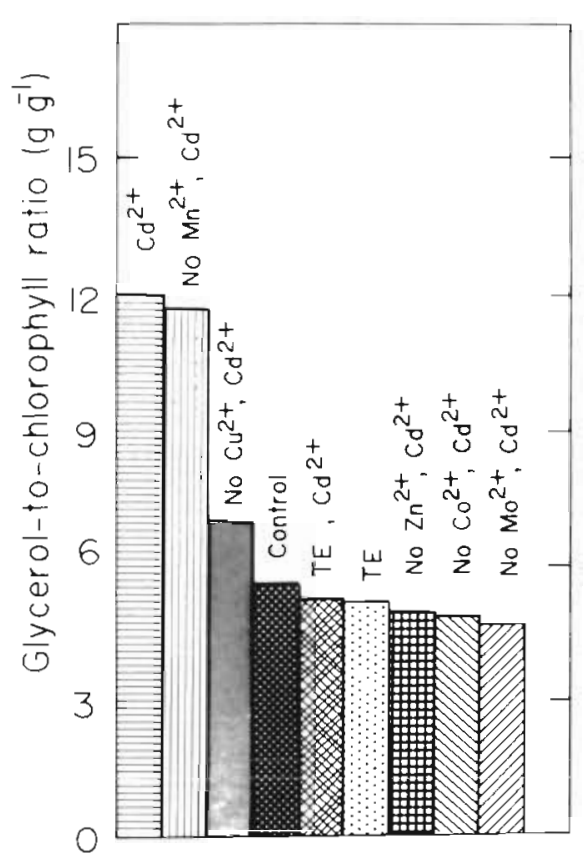

Fig. 4. Dunaliella salina. Effect of trace elements on the glycerol-to-chlorophyll ratio. Conditions were as described in Fig. 3

toxicated cells treated with manganese (Fig. 4). Increase of glycerol-to-chlorophyll ratio from the normal level of around 6 to the elevated level of above 11 always indicated $\mathrm{Cd}^{2+}$ toxicity in Dunaliella salina grown under the specified conditions.

\section{Cadmium uptake}

Table 1 shows cadmium uptake by Dunaliella salina grown in the presence of cadmium concentrations from as low as $9 \mu \mathrm{M} \mathrm{Cd}^{2+}$. Results are shown in $\mu \mathrm{g}$ per $\mathrm{mg}$ organic weight rather than in intracellular molar units, since the cell osmotic water and the cellular localization of cadmium were not determined. The content of cadmium in weight per cell organic weight therefore represents total uptake or adsorption by $D$. salina. Manganese inhibited cadmium uptake and antagonized the accumulation of cadmium, corresponding to the protective effect of manganese on the algal growth.

\section{Mechanism of cadmium-manganese interaction}

Fig. 5. shows the inhibitory effect of cadmium on Dunaliella salina in the presence of different concentrations of manganese. Reciprocal plots of the data with regard to specific growth rate and biomass level show competitive inhibition between cadmium and manganese (Figs. $6 \& 7$ ). The following values of $\mathrm{Ks}$ were
Table 1. Dunaliella salina. Effect of $\mathrm{Mn}^{2+}$ on uptake of $\mathrm{Cd}^{2+}$ $D$. salina was grown in an artificial medium in the presence of the indicated concentrations of $\mathrm{Cd}^{2+}$ Algae were assayed for $\mathrm{Cd}^{2+}$ uptake at the end of the logarithmic phase.

\begin{tabular}{|ccc|}
\hline $\begin{array}{c}\text { Initial } \mathrm{Cd}^{2+} \\
\text { concentration }\end{array}$ & $\begin{array}{c}\mathrm{Cd}^{2+} \text { uptake } \\
\text { Control } \\
+10 \mu \mathrm{M} \mathrm{Mn}^{2+} \\
\mu\end{array}$ & \\
\hline 9 & 0.3 & 0.15 \\
45 & 1.0 & 0.51 \\
90 & 1.4 & 0.78 \\
\hline
\end{tabular}

calculated: $\mathrm{Ks}[\mathrm{Cd}=0]=0.175, \mathrm{Ks}[\mathrm{Cd}=45 \mu \mathrm{M}]=$ $0.175, \mathrm{Ks}[\mathrm{Cd}=90 \mu \mathrm{M}]=0.126, \mathrm{Ks}[\mathrm{Cd}=135 \mu \mathrm{M}]=$ 0.1 . The inhibition by cadmium showed $\mathrm{Ki}[\mathrm{Mn}=0]=$ 0.01 . The competitive inhibition by cadmium is of a hyperbolic type (Fig. 7, lower) which indicates that there is no formation of a complex between the inhibitor and the target (or the membrane site), and the effect is on the affinity site of the enzyme for the manganese. Attempts to improve the kinetic analysis by minimizing the manganese concentration in the medium were unsuccessful due to the unavoidable presence of trace amounts of manganese in the $\mathrm{NaCl}$. Commercial analytical grade $\mathrm{NaCl}$ provided about

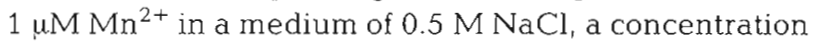
high enough to support growth of $D$. salina.

\section{DISCUSSION}

Low concentrations of cadmium caused partial chlorosis and low chlorophyll content per cell in a culture of Dunaliella salina presenting normal cell division. Above $45 \mu \mathrm{M}$ cadmium, cell division was impaired, but since the biosynthesis of the osmoregulator glycerol and probably other carbohydrates was not impaired, and their synthesis continued at the optimal rate, the volume of the algae increased. It was interesting to note that cadmium toxicity did not affect the biosynthesis of glycerol and that $D$. salina could maintain its osmoregulation under conditions where the culture was heavily toxicated by cadmium. High resistance of the glycerol biosynthetic machinery in Dunaliella to protein biosynthetic inhibitors and the lack of specific inhibitor enzymes in the glycerol cycle (Ben-Amotz \& Avron 1978) have already pointed to the independence of glycerol metabolism in this halotolerant alga. Cadmium toxicity in D. salina is, therefore, metabolic specific, inhibiting initially chlorophyll formation, subsequently (at higher concentrations of cadmium) protein biosynthesis, and finally cell division. This cell swelling has some similarity to results from the work of Fisher et al. (1981) on the effect of elevated 

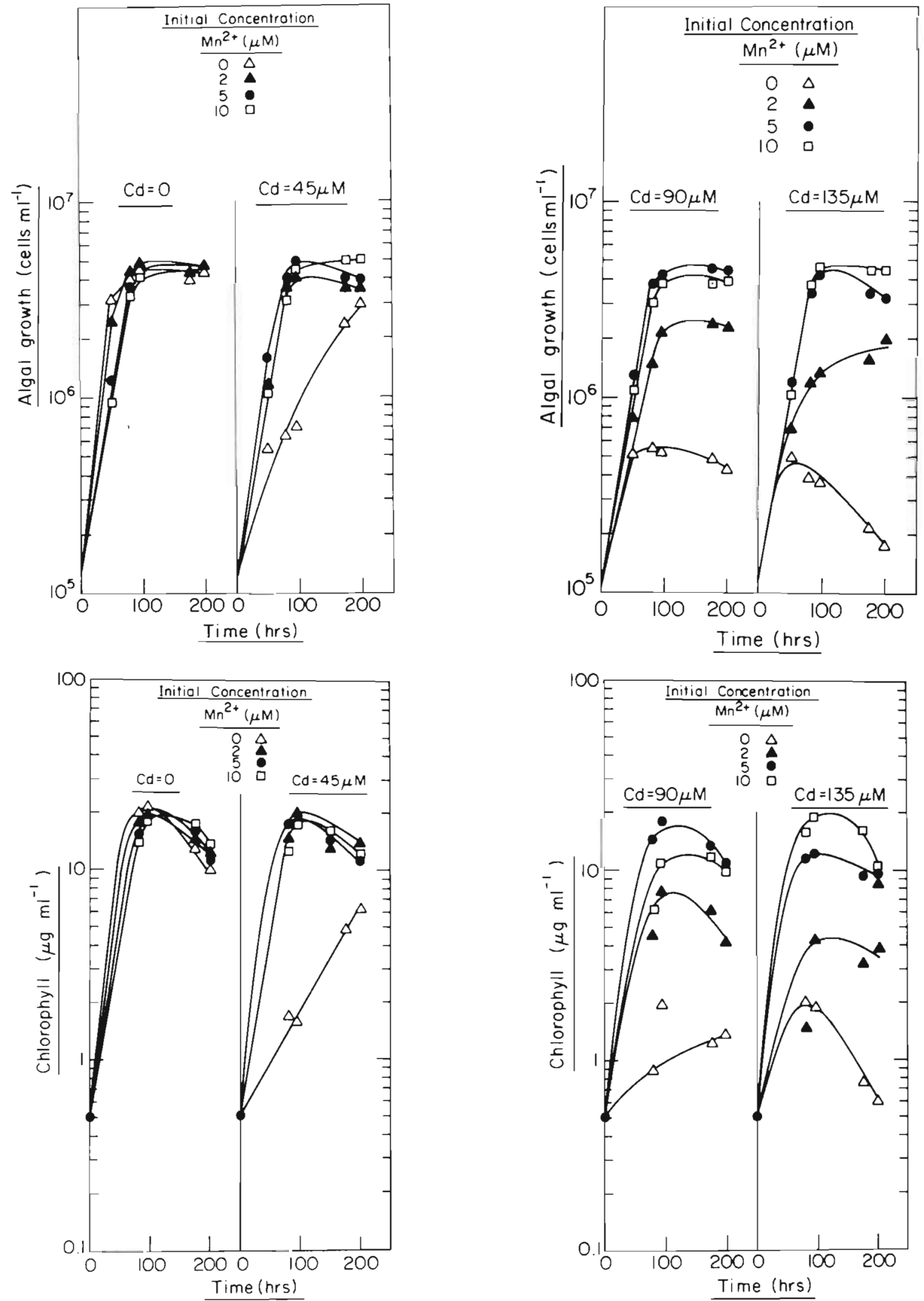

Fig. 5. Dunaliella salina. Inhibitory effect of $\mathrm{Cd}^{2+}$ in the presence of different concentrations of $\mathrm{Mn}^{2+} \mathrm{Upper}^{2}$ cells; lower: chlorophyll. Growth conditions as described in 'Materials and Methods' 

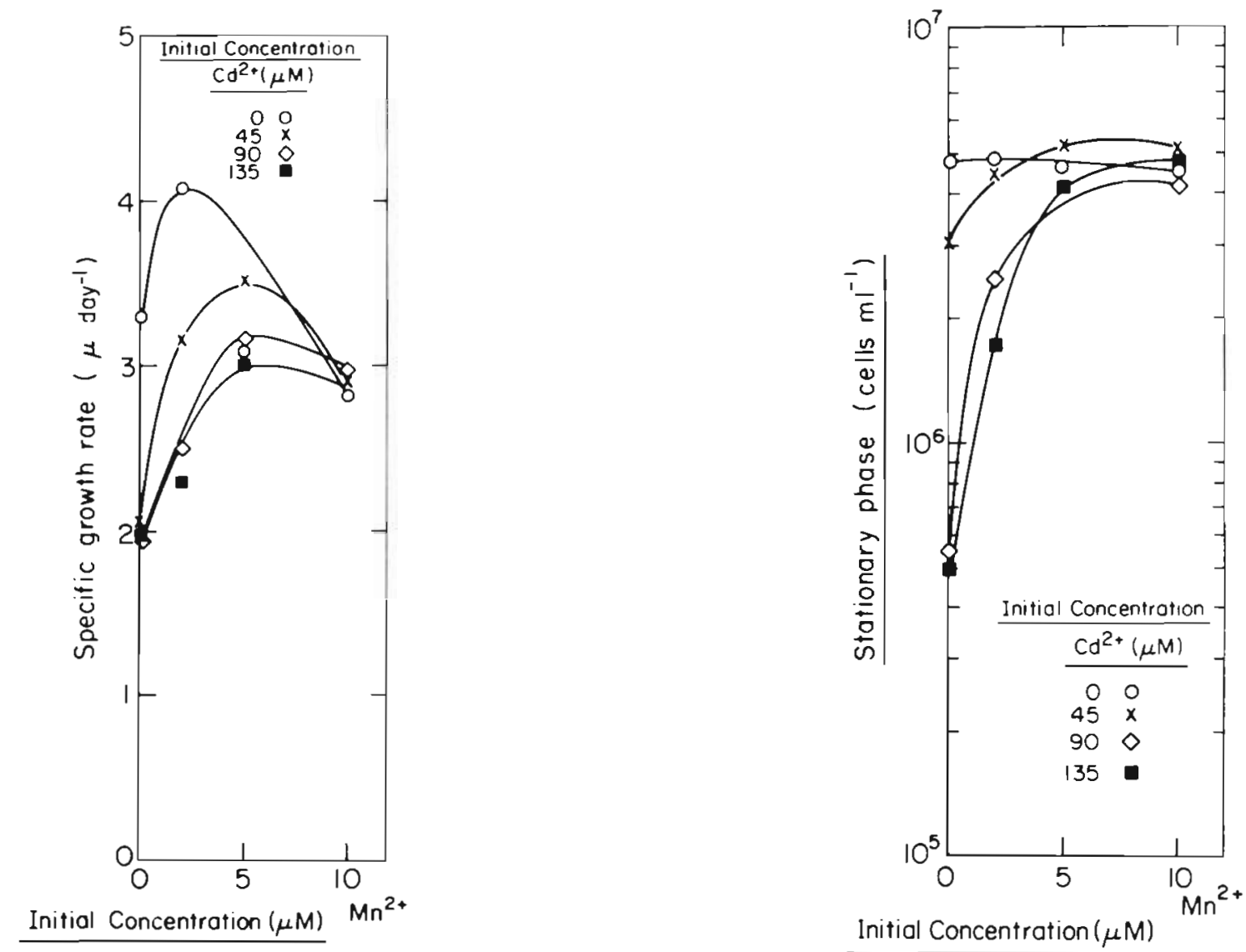

Fig. 6. Dunaliella salina. Antagonistic effect of $\mathrm{Mn}^{2+}$ on $\mathrm{Cd}^{2+}$ toxicity with regard to the specific growth rate (left) and stationary phase (right). A specific growth rate of 2 represents doubling every $24 \mathrm{~h}$

levels of copper and zinc on the growth, morphology and metabolism of Asterionella japonica, as expressed by reduction of cell division and increase in cell size. Increase in cell size is presumably dependent, however, on the continuous production of cellular soluble osmotic components which will in turn cause water influx and cell size enhancement.

Previous studies by Sunda et al. (1981) showed antagonistic interaction between copper toxicity and manganese in marine phytoplankton, and that a combination of low manganese concentrations and high cupric ion activities may limit the growth of phytoplankton in upwelling seawater. Our study of Dunaliella salina growth in the presence of different trace elements clearly identifies manganese as the antagonist cation to cadmium. The presence of manganese in cultures of $D$. salina exposed to cadmium at the investigated levels is essential for normal chlorophyll synthesis.

The increased cadmium uptake in the absence of manganese or of all 5 trace elements confirmed our conclusion that cadmium interferes with the process of pigment biosynthesis in Dunaliella salina. Manganese deprivation in algae is known to cause chlorosis and to interfere with the maintenance of the chloroplast membrane structure and with the electron transport of Photosystem II (L'Kelley 1974, Rains 1976). Cadmium toxicity as analysed by competitive inhibition with manganese showed a similar effect on $D$. salina: chlorosis and cell death. The sequence of events which caused the inhibition of cell growth may be hypothesized as indicating a series of events starting with cadmium competition with manganese, continuing via manganese deprivation, disintegration of the chloroplast membrane, and chlorosis, and eventually leading to interference of cell division.

To explain the relation between the effect of cadmium, manganese and the growth of Dunaliella salina, we have used the classical enzyme kinetics model where manganese functions as a substrate (S), cadmium as an inhibitor (I), the alga as an enzyme (E), and the growth rate as velocity (V). The kinetics of most enzymic reactions in the presence of varying concentrations of inhibitors are characterized by linear double reciprocal plots of $1 / \mathrm{V}$ versus $1 / \mathrm{S}$, but the slope, the intercept, or both are altered by factors $\left(1+i / k_{13}\right)$ where $i$ 

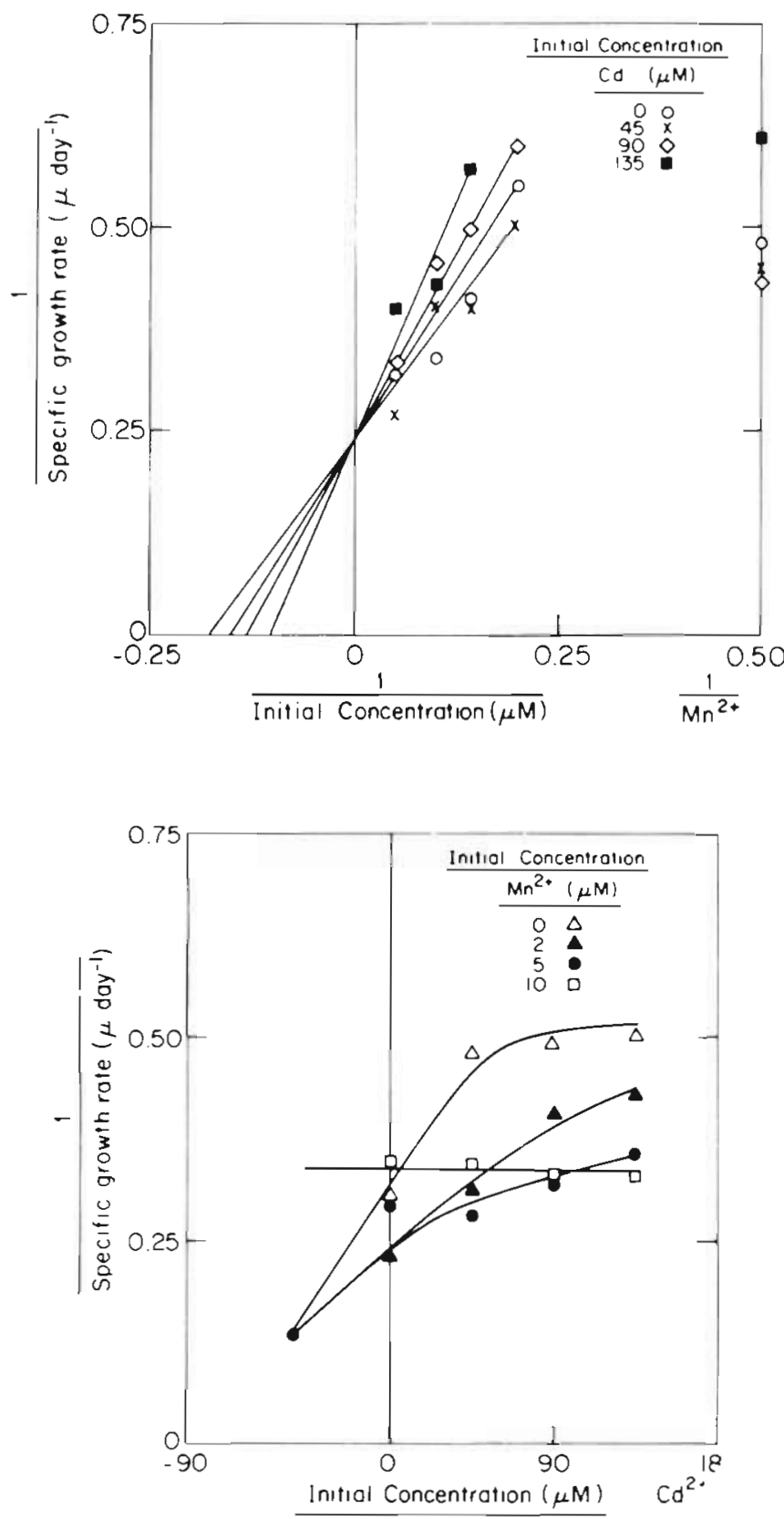

Fig. 7. Dunaliella salina. Kinetic diagnostic for competitive inhibition of $\mathrm{Mn}^{2+}$ to $\mathrm{Cd}^{2+}$ toxicity. Data illustrated were derived from Fig. 6

is the concentration of the inhibitor and $k_{i j}$ is a characteristic constant. Plots of $\mathrm{V}$ vs $\mathrm{i}$ as well as secondary replots of slopes or interceptors versus i may or may not be linear because the effect on the steady-state rate equation itself is that certain denominator terms are multiplied by the same factor $\left(1+\mathrm{i} / \mathrm{k}_{1}\right)$ (Mahler \& Condes 1966).

The kinetic analysis in our study (Figs. 5 to 7) clearly showed a specific hyperbolic competitive cadmiummanganese interaction. The hyperbolic plot of $1 / \mathrm{V}$ ver- sus i showed that there is not formation of EI or IES as in pure competitive inhibition, but the effect of cadmium is on the affinity of $\mathrm{E}$ for $\mathrm{S}$ only. Hyperbolic competition may be regarded as an instance of allosteric inhibition.

Our results do not specify which of the possible competitive inhibitions takes place: cell membranal or intracellular. Both mechanisms would fit the effect of cadmium on the manganese requirement. Cadmium may interfere with manganese uptake and its transfer across the membrane by blocking the manganese channel in the membrane, or by replacing manganese with cadmium to facilitate active uptake of toxic cadmium from the medium into the cell by the manganese carrier. In either case, a phenomenon of manganese deficiency would be shown and the algae would manifest manganese starvation symptoms. The MichaelisMenten analysis cannot distinguish between these 2 possibilities, as the kinetics equation is similar for nutrient uptake by a membrane carrier and for enzymatic catalysis. The question of the exact site of cadmium interference with manganese utilization in the cell remains open for further studies, but the implication of this study may be that unicellular marine algae can be adapted to survive in trace-metal polluted aquatic environments. Whenever a toxic level of a heavy metal is antagonized by an appropriate level of a nutrient metal, the algal hyperbolic competitive protection mechanism may allow the cell to maintain its biological activity.

\section{LITERATURE CITED}

Bariaud, A., Bury, M., Mestre, J. C. (1985). Mechanism of $\mathrm{Cd}^{2+}$ resistance in Euglena gracilis. Physiologia plant. 63: 382-386

Ben-Annotz, A. Avron, M. (1978). On the mechanism of osmoregulation in Dunaliella. In: Caplan, S. R., Ginzburg, M. (eds.) Energetics and structure of halophilic organisms. Elsevier, Amsterdam, p. 529-541

Bryan, G. W. (1971). The effect of heavy metals (other than mercury) on marine and estuarine organisms. Proc. R. Soc. B177: $389-410$

Conway, H. L., Williams, S. C. (1979). Sorption of cadmium and its effect on growth and utilization of inorganic carbon and phosphorus of two freshwater diatoms. J. Fish. Res. Bd Can. 36: 579-586

De Filippis, L. F., Hampp, R., Ziegler, H. (1981). The effects of sublethal concentrations of zinc, cadmium and mercury on Euglena. II. Respiration, photosynthesis and photochemical activities. Arch. Mikrobiol. 128: 404-411

Fisher, N.S., Jones, G. J., Nelson, D. M. (1981). Effect of copper and zinc on growth, morphology and metabolism of Asterionella japonica (Cleve). J. exp. mar. Biol. Ecol. 51: $37-56$

Gipps, J. F., Coller, A. W. (1980). Effect of physical and culture conditions on uptake of cadmium by Chlorella pyrenoidosa. Aust. J. mar. Freshwat. Res. 31: 745-755 
Hart, B. A., Bertram, P. E., Scaife, B. D. (1979). Cadmium transport by Chlorella pyrenoidosa. Environ. Res. 18: $327-335$

Hart, B. A., Scaife, B. D. (1977). Toxicity and bioaccumulation of cadmium in Chlorella pyrenoidosa. Environ. Res. 14: $401-413$

Jennings, J. R., Rainbow, P. S. (1979). Accumulation of cadmium by Dunaliella tertiolecta Butcher. J. Plankton Res. 1: $67-74$

Jensen, A. (1978). Chlorophylls and carotenoids. In: Hellebust, J. A., Craigie, J. S. (ed.) Handbook of phycological methods: physiological and biochemical methods. Cambridge Univ. Press, London, p. 59-70

Kayser, H., Sperling, K. R. (1980). Cadmium effects and accumulation in cultures of Prorocentrum micans (Dinophyta). Helgoländer Meeresunters. 33: 89-102

Li, W. K.W. (1980). Cellular accumulation and distribution of cadmium in Isochrysis galbana during growth inhibition and recovery. J. Plankton Res. 2: 283-294

Mahler, H. R., Cordes, E. H. (1966). Biological chemistry. Harper \& Row, New York

Nomiyama, K. (1975). Toxicity of cadmium - mechanism and diagnosis. Heavy metals in the aquatic environment - an international conference. Pergamon Press, Oxford

O'Kelley, J. C. (1974). Inorganic nutrients. In: Stewart, W. D. P. (ed.) Algal physiology and biochemistry. Blackwell, Oxford, p. 610-635

Parkinson, G., Ushio, S., Hunter, D., Sandler, N. (1987). New techniques may squeeze more chemicals from algae. Chem. Engng Prog. Symp. Ser. 11: 19-22

Prosi, F. (1981). Heavy metals in aquatic organisms. In: Foerstner, U., Witman, C. T. W. (eds.) Metal pollution in the aquatic environment. Springer-Verlag. New York, p. 285-289

Rabsch, U., Elbrächter, M. (1980). Cadmium and zinc uptake, growth and primary production in Coscinodiscus granii cultures obtaining low level of cells and dissolved organic carbon. Helgoländer Meeresunters. 33: 79-88
Rachlin, J. W., Warkentine, B., Jensen, T. E. (1982). The growth responses of Chlorella saccharophila, Navicula incerta and Nitzschia closterium to selected concentrations of cadmium. Bull. Torrey bot. Club 109: 129-135

Rachlin, J. W., Warkentine, B., Jensen, T. E. (1983). The response of the marine diatom Nitzschia closterium to selected concentrations of the divalent cations $\mathrm{Cd}, \mathrm{Cu}, \mathrm{Pb}$ and $\mathrm{Zn}$. In: Hemphil, D. D. (ed.) Trace substances in environmental health, XVII. Univ. of Missouri, Columbia, p. $72-81$

Rains, D. W. (1976). Mineral metabolism. In: Bonner, J., Varner, J. E. (ed.) Plant biochemistry, 3rd edn. Academic Press, New York, p. 561-597

Rebhun, S., Ben-Amotz, A. (1984). The distribution of cadmium between the marine alga Chlorella stigmatophora and sea water medium. Wat. Res. 18: 173-178

Rebhun, S., Ben-Amotz, A. (1986). Effect of $\mathrm{NaCl}$ concentration on cadmium uptake by the halophilic alga Dunaliella salina. Mar. Ecol. Prog. Ser. 30: 215-219

Rosko, J. J., Rachlin, J. W. (1975). The effect of copper, zinc, cobalt and manganese on the growth of the marine diatom Nitzschia closterium. Bull. Torrey bot. Club 102: 100-106

Sunda, W. G., Barber, R. T., Huntsman, S. A. (1981). Phytoplankton growth in nutrient rich seawater: importance of copper-manganese cellular interaction. J. mar. Res. 39 $567-586$

Wolter, K. Rabsch, U., Krischker, P., Davies, A. G. (1984) Influence of low concentrations of cadmium, copper and zinc on phytopiankton of natural water samples. Mar. Ecol Prog. Ser. 19: 167-173

Weigel, H. J. (1985). The effect of $\mathrm{Cd}^{2+}$ on photosynthetic reactions of mesophyll protoplasts. Physiologia plant. 63 $192-200$

Wikfors, G. H., Ukeles, R. (1982). Growth and adaptation of estuarine unicellular algae in media with excess copper cadmium or zinc, and effects of metal-contaminated algal food on Crassostrea virginica larvae. Mar. Ecol. Prog. Ser 7. $101-206$ 


\title{
Results of ecological monitoring of three beaches polluted by the 'Amoco Cadiz' oil spill: development of meiofauna from 1978 to 1984
}

\author{
P. Bodin \\ Université de Bretagne Occidentale, Faculté des Sciences, Laboratoire d'Océanographie Biologique, U.A. 711 du C.N.R.S., \\ 6 Avenue Le Gorgeu, F-29287 Brest Cedex, France
}

\begin{abstract}
Following the 'Amoco Cadiz' oil spill, time-series sampling of the meiofauna was carried out from 1978 to 1984 in the intertidal zone of 3 sandy beaches on the northern Finistère coast (Brittany, France). Quantitative analysis documented 2 principal phases in the development of the main taxa (Nematoda and Copepoda). First came a degradation phase leading to impoverishment in density and diversity of the populations. This first phase could be subdivided into several stages corresponding mainly to the toxicity period and, on one beach (Kersaint), to a summer 'bloom'. Then came a recovery phase corresponding to a quantitative and qualitative reconstitution of the meiofauna. Each phase lasted a greater or lesser time according to station exposure and the considered taxon. A qualitative analysis of harpacticoid copepods illustrated the development of population diversity and ecological groups'. During the first phase, replacement of the original population by a substitute fauna was observed. Correspondence factorial analysis on the development of harpacticoid communities allowed a better understanding of the main pollution and recovery factors such as toxicity, organic matter, hydrodynamism and zoological groups. Meiofauna, particularly harpacticoid copepods, are significant bioindicators of ecological disturbances.
\end{abstract}

\section{INTRODUCTION}

Few long-term studies on meiofauna exist, particularly any dealing with the consequences of oil pollution (Feder et al. 1976, Boucher 1983, 1985, Elmgren et al. 1983).

Following the wreck of the oil tanker 'Amoco Cadiz' (16 March 1978), time-series sampling of the meiofauna was carried out from 1978 to 1984 in the intertidal zone of 3 sandy beaches on the northern Finistère coast (Brittany, France). Two of these beaches (Brouennou and Corn ar Gazel) are situated on either side of the mouth of the Aber Benoit river; the third (Kersaint) about $4 \mathrm{~km}$ south of the wreckage point, near Portsall (Fig. 1). Preliminary results of this ecological monitoring were presented in 2 previous papers (Bodin \& Boucher 1981, 1983) and several reports. The aim of the present paper is to synthesize the final results. Special attention is paid to the 2 principal zoological groups involved: nematodes and harpacticoid copepods.

\section{MATERIAL AND METHODS}

Study sites. Brouennou is a fine-sand beach (median grain size 127 to $160 \mu \mathrm{m}$ ), poorly sorted, containing 1.7 to $6.6 \%$ silt/clay and 0.2 to $0.3 \%$ organic carbon (Table 1, Fig. 2). It faces west, but a rocky point and several small islands shelter it from open sea swells. Its 'morpho-sedimentary vulnerability index' is 6 (Berné \& D'Ozouville 1979). On this vulnerability scale, ranging from 1 to 10 , low figures mean greater exposure to wave and current action.

Corn ar Gazel is a fine-sand beach (median grain size 122 to $150 \mathrm{um}$ ), well sorted, containing 0.9 to $2.2 \%$ silt/ clay and 0.3 to $0.4 \%$ organic carbon. It faces northeast and is under the influence of strong tidal currents as well as wave action. Its morpho-sedimentary vulnerability index is 2 .

Kersaint has coarser sand (median grain size 191 to $210 \mu \mathrm{m}$ ), well sorted, containing 0.9 to $2.4 \%$ silt/clay and about 0.1 to $0.3 \%$ organic carbon. It faces northnorthwest and, consequently, is exposed to the strong 